\title{
MENINGKATKAN HASIL BELAJAR PPKn MELALUI MODEL PEMBELAJARAN KOOPERATIF TIPE JIGSAW PADA SISWA KELAS VIII.D SMP NEGERI 20 KENDARI
}

\author{
Nurmaulid, Hamuni, Abdul Syaban \\ Jurusan Pendidikan Pancasila dan Kewarganegaraan \\ Fakultas Keguruan dan Ilmu Pendidikan \\ Universitas Halu Oleo \\ Email.nurmaulid@gmail.com, hamunifaturrahman@gmail.com, \\ abdulsyaban1992@gmail.com
}

\begin{abstract}
Abstrak: Tujuan penelitian ini adalah untuk meningkatkan aktivitas belajar siswa, aktivitas pembelajaran yang dilaksanakan guru, dan hasil belajar PPKn siswa melalui model pembelajaran kooperatif tipe Jigsaw pada siswa kelas VIII.D SMP Negeri 20 Kendari. Jenis penelitian ini adalah penelitian tindakan kelas (PTK) yang dilaksanakan dalam dua siklus. Tiap siklus terdiri dari dua pertemuan yang meliputi perencanaan, pelaksanaan, pengamatan, dan refleksi. Subjek penelitian ini adalah 30 orang siswa kelas VIII.D SMP Negeri 20 Kendari. Jenis data dalam penelitian ini adalah data kuantitatif berupa data hasil belajar dan data kualitatif diperoleh melalui lembar observasi.

Penerapan model pembelajaran kooperatif tipe Jigsaw membawa dampak positif berupa peningkatan aktivitas belajar siswa, aktivitas pembelajaran yang dilaksanakan oleh guru, dan peningkatan hasil belajar PPKn siswa. Aktivitas belajar pada siklus I sebesar $64,70 \%$ mengalami peningkatan sebesar $23,53 \%$ menjadi $88,23 \%$ pada siklis II. Aktivitas pembelajaran juga pada siklus I sebesar $63,63 \%$ mengalami peningkatan sebesar 27,28\% pada siklus II menjadi 90,91\%. Hasil belajar siswa pada observasi awal mencapai 33,33\% dan pada siklus I sebesar 53,33\% dan pada siklus II menjadi 83,33\%.

Kesimpulan yaitu aktivitas belajar siswa, aktivitas pembelajaran yang dilaksanakan guru, dan hasil belajar PPKn siswa kelas VIII.D SMP Negeri 20 Kendari dapat ditingkatkan melalui model pembelajaran kooperatif tipe Jigsaw.
\end{abstract}

\section{Kata Kunci: Hasil Belajar, Pembelajaran, Kooperatif Tipe Jigsaw.}

\section{PENDAHULUAN}

Pendidikan merupakan aspek yang paling mendasar bagi pembangunan suatu bangsa. Lewat proses pendidikan kemampuan dasar yang fundamental baik menyangkut daya pikir atau daya intelektual, maupun daya emosional diarahkan kepada tabiat manusia dan kepada sesamanya sebagaimana telah dirumuskan dalam UU NO. 20 Tahun 2003 secara tegas dalam Pasal 3 disebutkan bahwa "Pendidikan nasional berfungsi mengembangkan dan membentuk watak serta peradaban bangsa yang bermartabat dalam rangka mencerdaskan keghidupan bangsa, bertujuan untuk berkembangnya potensi peserta didik agar menjadi manusia yang beriman dan bertakwa kepada Tuhan Yang Maha Esa, berakhlak mulia, sehat, berilmu, cakap, kreatif, mandiri, dan menjadi warga negara yang demokratis serta bertanggung jawab".

Pendidikan sebagai sebuah sistem dalam prosesnya harus terdapat perencanaan, pelaksanaan, serta evaluasi. Semua itu ditujukan untuk mencetak generasi yang matang dalam segala bidang, baik sains, teknologi, agama, dan pengetahuan lainnya, sehingga anak didik mampu menjadi manusia bermoral dan berpengatahuan. Dalam pembelajaran terdapat dua kegiatan yang saling sinergi 
yakni antara guru sebagai pengajar dan siswa sebagai pembelajaran. Guru tidak hanya berperan membelajarkan siswa tetapi berperan pula dalam usaha meningkatkan motivasi dan hasil belajar yang optimal.

Berdasarkan hasil obsevasi dan wawancara awal pada tanggal 6 Maret dengan guru PPKn (Niya Sriwanti Samad) menyatakan bahwa untuk kelas VIII di SMP Negeri 20 Kendari berjumlah 6 (enam) kelas. Namun dari 6 (enam) kelas tersebut untuk mata pelajaran PPKn pada semester I (ganjil) tahun pelajaran 2018/2019 kelas VIII.D memiliki persentase nilai KKM paling rendah. Hal itu dibuktikan dari 31 orang siswa (14 orang siswa laki-laki dan 17 orang siswi perempuan) yang mengikuti proses pembelajaran hanya 12 siswa yang memenuhi KKM atau 38,71 \%, yang mendapatkan nilai minimal 72 sedangkan yang tidak memenuhi standar sebanyak 19 orang atau $61,29 \%$ dari standar nilai KKM yang ditentukan sekolah yaitu 72 .

Oleh karena itu dibutuhkan adanya alternatif pembelajaran yang berorientasi pada perbaikan proses pembelajaran. Salah satu alternatif yang dapat digunakan adalah menggunakan pembelajaran kooperatif tipe Jigsaw. Menurut Suyanto dan Asep Djihad (2013 :168) menyatakan bahwa cooperatif learning tipe jigsaw adalah salah satu tipe pembelajaran kooperatif yang mendorong siswa aktif dan saling membantu dalam menguasai materi pelajaran. Tujuannya tidak lain adalah mencapai hasil belajar yang maksimal baik individu maupun kelompok.

\section{Konsep Aktivitas Belajar}

\section{Aktivitas Belajar}

Menurut Sardiman (2014: 100) bahwa yang dimaksud aktivitas belajar adalah aktivitas yang bersifat jasmani maupun psikis. Aktivitas ini berarti dua perbuatan yang terkait. Perbuatan ini dapat menghasilkan belajar yang optimal apabila antara perbuatan jasmani seperti siswa yang sedang membaca dan perbuatan psikis seperti siswa berpikir tentang sesuatu, itu seimbang dan sebaliknya. Perbuatan seimbang itu yang dinamakan aktivitas belajar.

\section{Jenis- jenis Aktivitas}

Menurut Paul B. Diedrich (Sardiman, 2006: 101) menyatakan bahwa kegiatan siswa digolongkan sebagai berikut:

a. Visual activities, diantaranya meliputi membaca, memperhatikan gambar demonstrasi, percobaan.

b. Oral activities, seperti: menyatakan, merumuskan, bertanya, memberi saran, mengeluarkan pendapat, mengadakan wawancara, diskusi, interupsi.

c. Listening activities, sebagai contoh: mendengarkan: uraian, percakapan, diskusi, musik, pidato.

d. Writing activities, seperti misalnya menulis cerita, karangan, laporan, angket, menyalin.

e. Drawing activities, misalnya: menggambar, membuat peta, diagram, grafik.

\section{Konsep Belajar dan Pembelajaran}

\section{Konsep Belajar}

Menurut Kurniawan (2014: 4) menyatakan bahwa belajar adalah proses aktif internal individu dimana melalui pengalamannya berinteraksi dengan lingkungan menyebabkan terjadinya perubahan tingkah laku yang relatif permanen. Demikian halnya menurut Syah (2001: 94) belajar pada hakikatnya merupakan proses kognitif yang mendapat dukungan dari fungsi ranah psikomotor. 
Fungsi psikomotor dalam hal ini meliputi: mendengar, melihat, mengucapkan. Apa pun manifestasi belajar yang dilakukan siswa hampir dapat dipastikan selalu melibatkan fungsi ranah akalnya yang intensitas penggunaannya tentu berbeda dengan peristiwa belajar lainnya.

Irwantoro dan Yusuf Suryana (2016: 55) menyatakan bahwa ciri-ciri belajar, yaitu:

a. Adanya kemampuan baru atau perubahan. Perubahan tingkah laku tersebut bersifat pengetahuan (kognitif), keterampilan (psikomotor), maupun kebiasaan, nilai dan sikap (afektif).

b. Perubahan itu tidak berlangsung sesaat saja, melainkan menetap atau dapat disimpan.

c. Perubahan itu tidak terjadi begitu saja, melainkan harus dengan usaha, perubahan terjadi akibat interaksi dengan lingkungan.

d. Perubahan tidak semata-mata disebabkan oleh pertumbuhan fisik atau kedewasaan, tidak karena kelelahan, penyakit atau pengaruh obat-obatan.

\section{Konsep Pembelajaran}

Suprihatiningrum (2013: 75) berpendapat bahwa pembelajaran adalah serangkaian kegiatan yang melibatkan informasi dan lingkungan yang disusun secara terencana untuk memudahkan siswa dalam belajar.

Kegiatan pembelajaran melibatkan komponen-komponen yang satu dan yang lainnya saling terkait dan menunjang dalam upaya mencapai tujuan pembelajaran yang telah ditetapkan dalam program pembelajaran. Komponenkomponen dalam pembelajaran tersebut seperti guru, siswa, metode, lingkungan, media, dan sarana prasarana perlu ada. Agar kegiatan pembelajaran mencapai hasil yang maksimal perlu diusahakan faktor penunjang seperti kondisi pelajar yang baik, fasilitas dan lingkungan yang mendukung, serta proses belajar yang tepat.

Menurut Gagne (Kurniawan, 2014: 27) menyatakan bahwa pembelajaran adalah serangkaian aktivitas untuk membantu mempermudah seseorang belajar, sehingga terjadi belajar secara optimal. Selanjutnya Aqib (2013: 66) menyatakan bahwa pembelajaran adalah upaya secara sistematis yang dilakukan guru untuk mewujudkan proses pembelajaran berjalan secara efektif dan efisien yang dimulai dari perencanaan, pelaksanaan, dan evaluasi.

\section{Hasil Belajar}

Menurut Kingsley (Kurniawan, 2014: 9) bahwa hasil belajar siswa (individu) menjadi tiga jenis yaitu: 1) keterampilan dan kebiasaan, 2) pengetahuan dan pengertian, 3) sikap dan cita-cita. Demikian halnya Hamalik (2006: 155) menyebutkan bahwa: "Hasil belajar adalah sebagai terjadinya perubahan tingkah laku pada diri seseorang yang dapat diamati dan diukur bentuk pengetahuan, sikap, dan keterampilan. Perubahan tersebut dapat diartikan sebagai terjadinya peningkatan dan pengembangan yang lebih baik sebelumnya yang tidak tahu menjadi tahu".

\section{Model Pembelajaran Kooperatif Tipe Jigsaw}

\section{Pengertian Model Pembelajaran Kooperatif Tipe Jigsaw}

Menurut Suyanto dan Asep Djihad (2013: 168) menyatakan bahwa cooperative learning tipe Jigsaw adalah adalah salah satu tipe pembelajaran kooperatif yang mendorong siswa aktif dan saling membantu dalam menguasai materi pelajaran. Tujuannya tidak lain adalah mencapai prestasi yang maksimal baik individu maupun kelompok. 


\section{Sintaks Model Pembelajaran Kooperatif Tipe Jigsaw}

Adapun langkah-langkah model pembelajaran kooperatif tipe Jigsaw menurut Ibnu (2014: 123) adalah sebagai berikut:

a. Siswa dibagi atas beberapa kelompok (tiap kelompok anggotanya 5-6 orang).

b. Materi pelajaran diberikan kepada siswa dalam bentuk teks yang telah dibagibagi menjadi beberapa subbab.

c. Setiap anggota kelompok membaca subbab yang ditugaskan dan bertanggung jawab untuk mempelajarinya. Misalnya, jika materi yang disampaikan mengenai sistem ekskresi. Maka seorang siswa dari satu kelompok mempelajari tentang ginjal, siswa yang lain dari kelompok satunya mempelajari tentang paru-paru, begitu pun siswa lainnya mempelajari kulit, dan lainnya lagi mempelajari hati.

d. Anggota dari kelompok lain yang telah mempelajari subbab yang sama bertemu dalam kelompok ahli untuk mendiskusikannya.

e. Setiap anggota kelompok setelah kembali ke kelompoknya bertugas mengajar teman-temannya.

f. Pada pertemuan dan diskusi kelompok asal dikenai tagihan berupa kuis individu.

\section{Kelebihan Model Pembelajaran Kooperatif Tipe Jigsaw}

Menurut Sunarta (2016: 154) mengemukakan bahwa model pembelajaran kooperatif tipe Jigsaw memiliki beberapa kelebihan, yaitu:

a. Melatih peserta didik untuk bertanggung jawab secara individu maupun kelompok.

b. Melatih peserta didik untuk lebih aktif belajar, memahami materi, mengemukakan pendapat, pikiran konsep, sehingga masing-masing memberi kontribusi kepada pencapaian tujuan yang lain.

c. Tercipta suasana belajar yang akrab, saling bekerja sama, saling menghargai, dan saling membantu dalam menyelesaikan tugas bersama.

d. Kesuksesan salah satu peserta didik akan ditularkan kepada yang lain, tanpa menghalang-halangi kesuksesan orang lain.

Berdasarkan uraian latar belakang masalah tersebut, maka penulis tertarik untuk melakukan penelitian tindakan kelas dengan judul "Meningkatkan Hasil Belajar PPKn Melalui Model Pembelajaran Kooperatif Tipe Jigsaw Pada Siswa Kelas VIII.D SMP Negeri 20 Kendari”.

\section{METODE PENELITIAN}

\section{Setting Penelitian}

Penelitian ini dilaksanakan di kelas VIII.D SMP Negeri 20 Kendari semester ganjil tahun ajaran 2019/2020. Waktu penelitian ini dilaksanakan pada bulan AgustusSeptember 2019. Perbaikan pembelajaran dilaksanakan dalam dua siklus, setiap siklus dua kali pertemuan. PTK ini dilaksanakan untuk melihat peningkatan hasil belajar pada materi UUD Negara Republik Indonesia tahun 1945.

\section{Subjek Penelitian}

Subjek penelitian ini adalah seluruh siswa kelas VIII.D SMP Negeri 20 Kendari. Jumlah siswa kelas VIII.D SMP Negeri 20 Kendari 30 orang, terdiri dari 16 siswa laki-laki dan 14 siswa perempuan. 


\section{Jenis Penelitian}

Jenis penelitian ini adalah penelitian tindakan kelas (Class Room Action Research) dengan menerapkan pembelajaran model kooperatif tipe Jigsaw untuk meningkatkan hasil belajar siswa kelas VIII.D SMP Negeri 20 Kendari pada materi UUD Negara Republik Indonesia 1945.

\section{Faktor Yang Diteliti}

Ada tiga faktor yang diteliti yaitu:

1. Faktor siswa: yaitu mengobservasi aktivitas belajar siswa dalam kelompok diskusi selama proses pembelajaran PPKn kelas VIII.D dengan menggunakan model pembelajaran kooperatif tipe jigsaw.

2. Faktor guru: yaitu mengobservasi aktivitas guru dalam melaksanakan proses pembelajaran kooperatif tipe jigsaw untuk kemudian direfleksi.

3. Faktor hasil belajar: Untuk mengetahui ada tidaknya peningkatan hasil belajar PPKn siswa setelah dilaksanakan proses pembelajaran dengan menggunakkan model pembelajaran kooperatif tipe jigsaw.

\section{Teknik Pengumpulan Data}

1. Lembar Observasi

2. Tes Hasil Belajar

\section{Teknik Analisis Data}

Analisis data dalam penelitian ini menggunakan teknik analisis deskriptif kuantitatif dalam bentuk persentase, nilai rata-rata, serta disajikan pula dalam bentuk tabel dan grafik. Analisis deskriptif kualitatif digunakan pula untuk mengukur indikator kinerja berdasarkan kriteria ketuntasan minimal.

1. Mengkonversi skor tes hasil belajar menjadi nilai (N) skor 0-100 dengan menggunakan rumus:

$$
\mathrm{N}=\frac{\sum \text { skor diperoleh }}{\sum \text { skor maksimal }} \times 100 \%
$$

2. Menentukan tingkat pencapaian ketuntasan belajar dengan rumus:
a. Secara individual $=\frac{\text { nilai dicapai }}{\text { nilai ideal }} \times 100 \%$
b. Secara kelompok $=\frac{\text { nilai dicapai }}{\text { nilai ideal }} \times 100 \%$
c. Nilai klasikal $=\frac{\text { nilai dicapai }}{\text { nilai ideal }} \times 100 \%$

3. Menentukan persentase ketuntasan belajar mengunakan rumus:

$\%$ tuntas : $\frac{\sum f i}{n} \times 100 \%$

Keterangan:

$\sum f i$ : Jumlah siswa pada kategori ketuntasan belajar

$\mathrm{n}$ : Jumlah siswa secara keseluruhan

(Uzer Usman dan Setiawati, 2001 :139)

4. Menentukkan aktivitas belajar dan aktivitas guru menggunakkan rumus:

a. Analisis aktivitas guru

$$
S=\frac{R}{N} \times 100 \%
$$

Keterangan:

$\mathrm{S}=$ Nilai persen yang dicari 
$\mathrm{R}=$ Jumlah skor aktivitas guru

$\mathrm{N}-$ Skor maksimum aktivitas guru

b. Analisis aktivitas belajar siswa

( Purwanto, $2010: 45$ )

$\%$ KABS $=\frac{\text { Skor perolehan siswa }}{\text { Skor maksimum }} \times 100 \%$

( Rohani, $2004: 122$ )

\section{HASIL DAN PEMBAHASAN \\ Hasil penelitian}

Kegiatan dan pendahuluan

Pada tanggal 14 Agustus 2019 diadakan tes awal yang berlangsung selama 60 menit. Tes awal ini bertujuan untuk melihat sejauh mana siswa memahami materi yang telah diajarkan. Selain itu, nilai tes awal ini juga digunakan sebagai acuan dalam pembentukan kelompok. Pada tes awal ini hasil ketuntasan belajar siswa hanya mendapatkan persentase sebesar $33,33 \%$ sedangkan nilai rata-rata yang dicapai adalah 56,13.

1. Aktivitas belajar siswa kelas VIII.D berhasil ditingkatkan dengan menggunakan model pembelajaran kooperatif tipe Jigsaw. Aktivitas belajar pada siklus I sebesar 64,70\% dan meningkat pada siklus II menjadi 88,23\%, peningkatan sebesar $23,53 \%$.

2. Aktivitas guru dalam melaksanakan proses pembelajaran dikelas VIII.D berhasil ditingkatkan dengan menggunakkan model pembelajaran kooperatif tipe Jigsaw. Aktivitas guru dalam melaksanakan proses pembelajaran pada siklus I sebesar 63,63\% dan meningkat pada siklus II menjadi 90,91\%, peningkatan sebesar $27,28 \%$.

3. Hasil belajar PPKn siswa kelas VIII.D SMP Negeri 20 Kendari pada materi UUD Negara Republik Indonesia tahun 1945 berhasil ditingkatkan setelah menggunakan model pembelajaran kooperatif tipe Jigsaw. Persentase hasil belajar siswa sebesar 53,33\% dari seluruh siswa yang mencapai nilai minimal 72, meningkat persentasenya pada siklus II yaitu sebesar 83,33\% yang mencapai nilai minimal 72., peningkatannya sebesar $30 \%$.

\section{Pembahasan}

\section{Aktivitas Belajar Siswa}

Berdasarkan analisis data, diperoleh informasi aktivitas belajar siswa dalam proses pembelajaran PPKn pada materi Undang-Undang Dasar NRI Tahun 1945 melalui model pembelajaran kooperatif tipe jigsaw mengalami peningkatan pada setiap siklusnya yakni hasil observasi aktivitas belajar siswa siklus I mencapai tingkat keberhasilan $64,70 \%$ dan siklus II mencapai $88,23 \%$ dengan jumlah persentase sebesar $23,50 \%$.

Hasil persentase skor peningkatan aktivitas belajar siswa dapat digambarkan dalam histogram berikut ini: 
Gambar 4.1 Hasil Persentase Skor Peningkatan Aktivitas Belajar Siswa SMP Negeri 20 Kendari

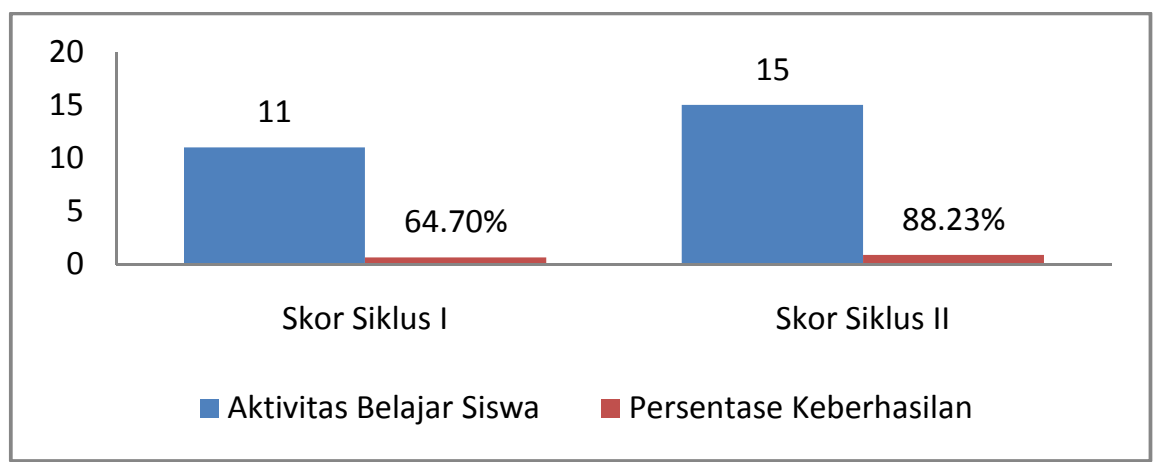

\section{Aktivitas Guru dalam Proses Pembelajaran}

Berdasarkan analisis data, diperoleh informasi bahwa aktivitas guru dalam proses pembelajaran dengan menerapkan model pembelajaran kooperatif tipe jigsaw pada setiap siklus mengalami peningkatan, yakni hasil observasi aktivitas guru dalam proses pembelajaran siklus I mencapai tingkat keberhasilan 63,63\% dan sikllus II mencapai 90,91\% dengan persentase peningkatan 27,28\%.

Hasil persentase skor peningkatan aktivitas guru dalam proses pembelajaran dapat digambarkan dalam histogram berikut ini:

Gambar 4.2 Hasil Persentase Skor Penilaian Aktivitas Guru dalam Proses Pembelajaran SMP Negeri 20 Kendari

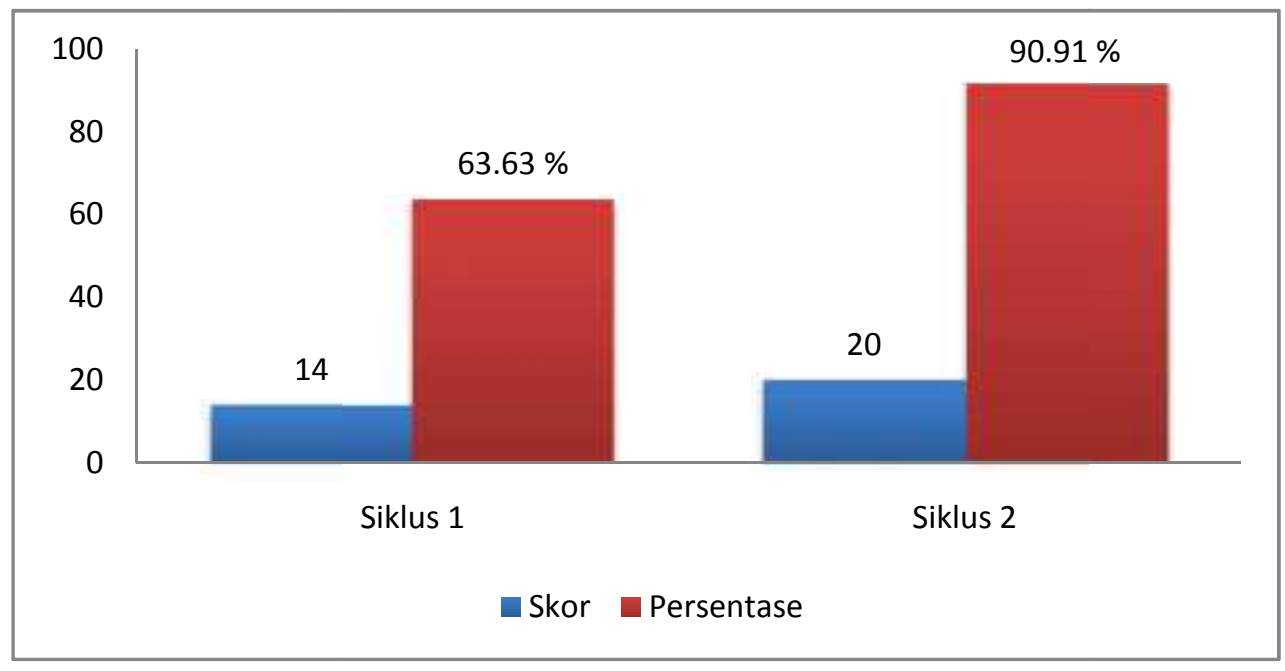

\section{Hasil Belajar PPKn Siswa}

Berdasarkan hasil observasi pada siklus I, menujukkan bahwa penerapan model pembelajaran kooperatif tipe jigsaw belum sempurna. Masih terdapat kekurangan-kekurangan yang harus diperbaiki. Hal ini terlihat dari hasil observasi yang dilakukan observer terhadap guru yang menunjukan masih ada hal-hal yang belum sepenuhnya terlaksana atau tuntas, seperti pemberian motivasi dan minat belajar yang masih kurang, guru tidak elakukan apersepsi dan guru belum 
sepenuhnya memberikan kesempatan kepada siswa dari kelompok lain untuk mengajukan tanggapan.

Deskripsi ketuntasan belajar PPKn siswa kelas VIII.D SMP Negeri 20 Kendari dapat dilihat pada tabel 4.18 berikut ini:

Tabel 4.16 Deskripsi Ketuntasan Belajar PPKn Siswa Kelas VIII.D SMP Negeri 20 Kendari

\begin{tabular}{|c|c|c|c|c|c|}
\hline \multirow{2}{*}{ No } & \multirow{2}{*}{ Jenis Evaluasi } & \multicolumn{3}{|c|}{ Kriteria ketuntasan } \\
\cline { 3 - 6 } & & \multicolumn{2}{|c|}{ Tuntas } & \multicolumn{2}{c|}{ Belum tuntas } \\
\cline { 3 - 6 } & & Jumlah & $\begin{array}{c}\text { Persentase } \\
(\%)\end{array}$ & Jumlah & $\begin{array}{c}\text { Persentase } \\
(\%)\end{array}$ \\
\hline 1. & Siklus I & 16 & $53,33 \%$ & 14 & $46,67 \%$ \\
2. & Siklus II & 25 & $83,33 \%$ & 5 & $16,67 \%$ \\
\hline
\end{tabular}

Sumber: Data Hasil Tes Belajar Siklus I dan Siklus II

Berikut disajikan Profil histogram ketuntasan belajar PPKn siswa kelas VIII.D SMP Negeri 20 Kendari pada siklus I dan siklus II.

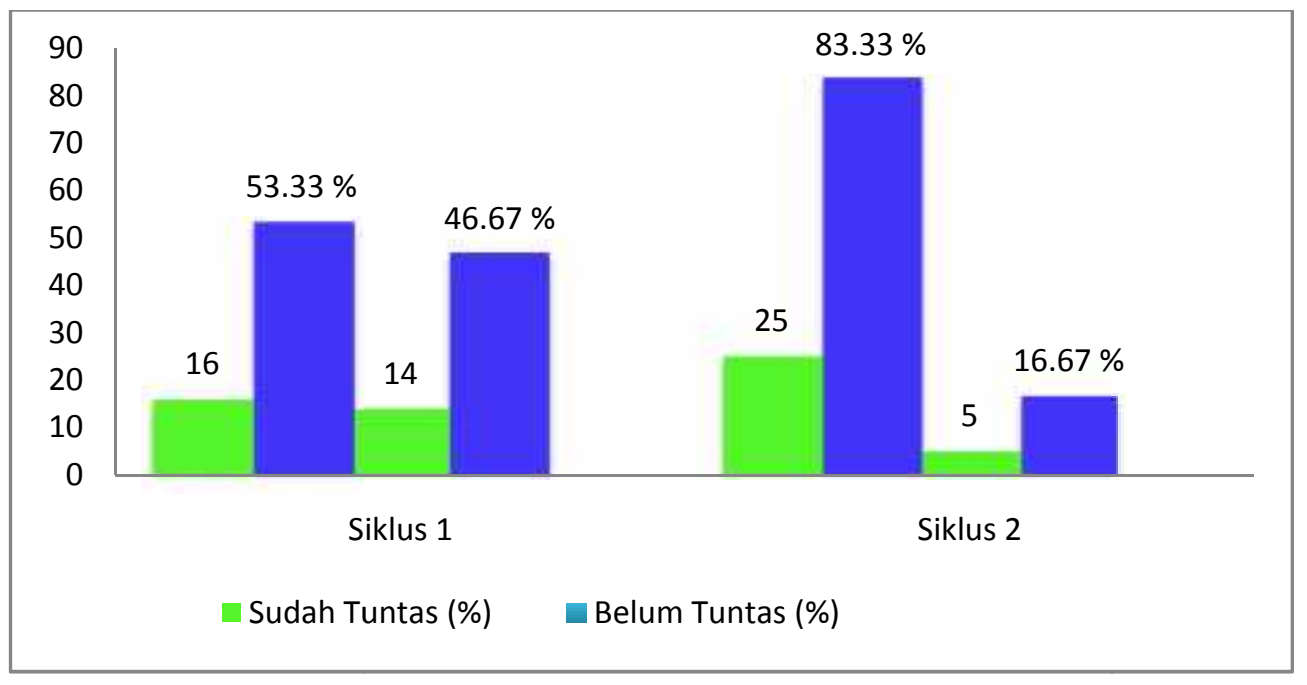

Gambar 4.1 Profil Ketuntasan Belajar PPKn Siswa Siklus I dan Sikllus II

Proses pembelajaran pada siklus I dan siklus II dijalankan dengan baik sesuai dengan rencana perbaikan pembelajaran yang ingin dicapai. Pada siklus I Proses pembelajaran belum dilakukan dengan baik, masih banyak terdapat siswa yang masih kaku dalam menggunakkan model pembelajaran kooperatif tipe jigsaw. Maka peneliti bersama guru melakukan refleksi terhadap proses pembelajaran yang dilaksanakan.

Berdasarkan hasil refleksi, peneliti dapat mengetahui kelemahan ataupun kelebihan sehingga dapat menentukkan upaya perbaikan dan menjadi rekomendasi pada siklus ke II. Dengan adanya proses pembelajaran yang dijalankan dengan baik dan perbaikan-perbaikan pembelajaran, maka berdampak pada aktivitas 
belajar siswa, aktivitas guru dalam melaksanakan proses pembelajaran dan hasil belajar PPKn siswa.

Berdasarkan hasil penelitian siklus I dan siklus II terlihat bahwa penerapan model pembelajaran kooperatif tipe Jigsaw dapat meningkatkan hasil belajar PPKn siswa, maka hipotesis dalam penelitian ini telah terjawab.

\section{PENUTUP}

\section{Kesimpulan}

1. Aktivitas belajar siswa kelas VIII.D berhasil ditingkatkan dengan menggunakan model pembelajaran kooperatif tipe Jigsaw. Aktivitas belajar pada siklus I sebesar 64,70\% dan meningkat pada siklus II menjadi 88,23\%, peningkatan sebesar 23,53\%.

2. Aktivitas guru dalam melaksanakan proses pembelajaran dikelas VIII.D berhasil ditingkatkan dengan menggunakkan model pembelajaran kooperatif tipe Jigsaw. Aktivitas guru dalam melaksanakan proses pembelajaran pada siklus I sebesar 63,63\% dan meningkat pada siklus II menjadi 90,91\%, peningkatan sebesar $27,28 \%$.

3. Hasil belajar PPKn siswa kelas VIII.D SMP Negeri 20 Kendari pada materi UUD Negara Republik Indonesia tahun 1945 berhasil ditingkatkan setelah menggunakan model pembelajaran kooperatif tipe Jigsaw. Persentase hasil belajar siswa sebesar $53,33 \%$ dari seluruh siswa yang mencapai nilai minimal 72, meningkat persentasenya pada siklus II yaitu sebesar 83,33\% yang mencapai nilai minimal 72., peningkatannya sebesar $30 \%$.

\section{Saran}

1. Bagi guru diharapkan dapat memahami dan mengetahui model pembelajaran kooperatif tipe Jigsaw dalam pembelajaran khususnya mata pelajaran PPKn untuk meningkatkan hasil belajar siswa.

2. Bagi siswa diharapakan lebih aktif mengikuti kegiatan pembelajaran sehingga dapat mempermudah memahami materi pelajaran dan memanfaatkan sumbersumber belajar yang telah disiapkan dari sekolah. Dengan demikian apabila keaktifan siswa ini terjadi seperti yang diharapkan maka akan meningkatkan hasil dan kualitas pembelajaran.

3. Bagi sekolah hendaknya dapat meningkatkan penggunaan model-model pembelajaran agar dapat meningkatkan kualitas proses dan hasil belajar siswa.

\section{DAFTAR PUSTAKA}

Aqib, Zainal. 2013. Model-Model, Media, dan Strategi Pembelajaran Kontekstual (Inovatif). Bandung: Yrama Widya.

Ibnu, Trianto Badar Al-Tabany. 2014. Mendesain Model Pembelajaran Inovatif, Progresif dan Kontekstual: Konsep, Landasan, dan Implementasinya Pada Kurikulum 2013 (Kurikulum Tematik Integratif/KTI). Jakarta: Prenadamedia Group.

Irwanto, Nur dan Yusuf Suryana. 2016. Kompetensi Pedagogik Untuk Meningkatkan dan Penilaian Kinerja Guru dalam Rangka Implementasi Kurikulum Nasional. Surabaya: Genta Group Production.

Kurniawan, Deni. 2014. Pembelajaran Terpadu Tematik (Teori, Praktik, dan

Penilaian). Bandung: Penerbit Alfabeta. 
Purwanto, N. 2010. Prinsip-Prinsip dan Teknik Evaluasi Pengajaran. Bandung: PT Remaja Rosdakarya.

Rohani, Ahmad. 2010. Pengelolaan Pengajaran. Jakarta: Rineka Cipta.

Sardiman. 2006. Interaksi dan Motivasi Belajar Mengajar. Jakarta: PT Raja Grafindo Persada.

----------. 2014. Interaksi dan Motivasi Belajar Mengajar. Depok: PT Raja Grafindo Persada.

Sunarta. 2016. Peningkatan Aktivitas dan Hasil Belajar PKn dengan Pembelajaran Kooperatif Tipe Jigsaw Di Kelas 8c SMP Negeri 3 Berbah. Jurnal Civics : Volume 13, Nomor 2, Desember 2016, hal 154.

Suprihatiningrum, Jamil. 2013. Srategi Pembelajaran (Teori dan Aplikasi). Jogjakarta: Ar-Ruzz Media.

Suyanto dan Asep Djihad. 2013. Bagaimana Menjadi Calon Guru dan Guru Profesional. Yogyakarta: Multi Pressindo.

Uzer, Usman dan Setiawati. 2001. Upaya optimalisasi kegiatan belajar mengajar.

Bandung: Remaja Rosada Karya 